УДК 656.223

\title{
АНАЛІЗ ФУНКЦІОНУВАННЯ ТРАНСПОРТНО-ПЕРЕСАДОЧНИХ ВУЗЛІВ НА ВИСОКОШВИДКІСНИХ ЗАЛІЗНИЧНИХ МАГІСТРАЛЯХ
}

Д-р техн. наук Д.В. Ломотько, магістрант І.Є. Марасіна

\section{АНАЛИЗ ФУНКЦИОНИРОВАНИЯ ТРАНСПОРТНО-ПЕРЕСАДОЧНЫХ УЗЛОВ НА ЖЕЛЕЗНОДОРОЖНЫХ ВЫСОКОСКОРОСТНЫХ МАГИСТРАЛЯХ}

Д-р техн. наук Д.В. Ломотько, магистрант И.Е. Марасина

\section{ANALYSIS OF THE FUNCTIONING OF TRANSPORT HUBS AT RAILWAY HIGH-SPEED HIGHWAYS}

Doct. of techn. Sciences D.V. Lomotko, master student I.E. Marasina

У даній статті подано необхідні критерії для створення ефективної, рентабельної комплексної транспортної системи великих міст. Крім того, виявлено основні напрямки розвитку сервісу пасажирських перевезень у великих транспортних вузлах, серед яких: розвиток інтелектуальних транспортних систем; інтеграчія рімень в області проїзних документів $i$ тарифної політики, збільшення провізної і пропускної спроможності магістралей $і$ т.д. Крім характеристик для ТПВ з участю швидкісного залізничного транспорту запропоновано використовувати додаткові критерії - планувальне рішення ТПВ, наявність і розміщення сервісцентру, наявність перехоплювального паркування. У якості прикладу проектування планувальної структури багатофункиіональних ТПВ швидкісного залізничного транспорту розглянуто комплексну модернізацію транспортної індраструктури на базі вокзального комплексу «Токійський вокзал», що проводиться в Японії в останні роки, яка дозволила досягти глибокої інтеграції систем міжрегіонального, регіонального залізничного, автомобільного $і$ міських видів пасажирського 
транспорту. У результаті запропоновано розглядати ТПВ як складний інфраструктурний комплекс, щчо включає в себе земельні ділянки з розтамованими на них, над ними чи під ними об'єктами транспортного та іншого призначення і призначений для забезпечення безпечного й комфортного обслуговування пасажирів в місиях пересадок з одного виду транспорту на інший.

Ключові слова: транспортно-пересадочний вузол (ТПВ), сервіс пасажирських перевезень, інфраструктурний комплекс, тарифна політика, модернізація.

В данной статье представлень необходимые критерии для создания эффективной, рентабельной комплексной транспортной системы крупных городов. Кроме того, выявлены основные направления развития сервиса пассажирских перевозок в крупных транспортных узлах, среди которых развитие интеллектуальных транспортных систем; интеграчия решений в области проездных документов и тарифной политики, увеличение провозной и пропускной способности магистралей и т.д. Кроме характеристик для ТПУ с участием скоростного железнодорожного транспорта, предложено использовать дополнительные критерии: планировочное решение ТПУ, наличие и размещение сервис-иентра, наличие перехватывающей парковки. В качестве примера проектирования планировочной структуры многофункииональных ТПУ скоростного железнодорожного транспорта рассмотрена комплексная модернизация транспортной инфраструктуры на базе вокзального комплекса «Токийский вокзал», проводимая в Японии в последние годы, которая позволила достигнуть глубокой интеграции систем межрегионального, регионального железнодорожного, автомобильного и городских видов пассажирского транспорта. В результате предложено рассматривать ТПУ как сложный инфраструктурный комплекс, включаюший в себя земельные участки с расположенными на них, над ними или под ними объектами транспортного и другого назначения и предназначенный для обеспечения безопасного $u$ комфортного обслуживания пассажиров в местах пересадок с одного вида транспорта на другой.

Ключевые слова: транспортно-пересадочный узел (ТПУ), сервис пассажирских перевозок, инфраструктурный комплекс, тарифная политика, модернизаиия.

This article presents the necessary criteria for creating efficient, cost-effective integrated transport system in the major cities. Furthermore identified the main directions of development of passenger transportation services in major transport hubs, including : the development of intelligent transport systems; integration of solutions in the field of travel documents and tariff policy, increase freight capacity and throughput of highways, etc. In addition to characteristics for TPU involving high speed rail is proposed to use additional criteria - planning decision TPU, availability and placement service center, the availability of bike Parking. As an example, the design of the planning structure of the multifunctional TPU speed rail transport is considered a comprehensive modernization of the transport infrastructure on the basis of the station complex "Tokyo station", held in Japan in recent years, which has enabled it to achieve a deep integration of systems of interregional, regional rail, road and urban types of passenger transport. As a result invited to consider the TPU as a sophisticated infrastructural facility which includes land located on them, over them or under them the objects of transport and other purposes, and designed to provide safe and comfortable passenger services in the field transfers from one vehicle to another.

Keywords: hub, service, passenger transportation, infrastructure complex, tariff policy, modernization.

Вступ. Одна 3 найважливіших незручностей великих міст і мегаполісів визначається необхідністю комплексної модернізації та нової структуризації транспортних мереж та інфраструктури транспорту шляхом формування i розвитку транспортно-пересадочних вузлів (ТПВ), що забезпечують найбільш ефективну взаємодію всіх елементів транспортної системи.
Постановка проблеми. Основною проблемою пасажирського залізничного транспорту $\epsilon$ повне задоволення потреб населення в перевезеннях. Незважаючи на вдосконалення процесів проектування i експлуатації транспортних систем пасажирського транспорту великих міст, тривалість переміщення пасажира з початкового пункту до кінцевого в них залишається значною i 
коливається залежно від розмірів міста в межах 35-90 хвилин. Час перебування пасажира в ТПВ становить приблизно чверть загального часу переміщення $[1,2]$.

Аналіз досліджень і публікацій. Виконані раніше наукові дослідження в даній сфері недостатньо враховували специфіку ринкової економіки, що впливає на функціонування і розвиток ТПВ $[5,6]$, а також зарубіжний досвід формування ТПВ [3, 4], їх проектування і розвиток у зв'язку з подальшим розвитком великих міст у взаємодії з різними видами пасажирського транспорту. Недостатньо використовувалися методологічний i математичний аналіз для прогнозування i моделювання динаміки та взаємодії пасажиропотоків у ТПВ [7, 8]. Питання функціонування, формування і розвитку ТПВ стали широко розглядатися в науковій спеціалізованій літературі з середини 60 -х років $\mathrm{XX}$ століття до сьогоднішнього дня $[10,11]$.

Формулювання мети (постановка завдання). Метою даних досліджень $\epsilon$ визначення необхідних критеріїв для створення ефективної, рентабельної комплексної транспортної системи великих міст; а також не тільки виявлення основних напрямків розвитку сервісу пасажирських перевезень у великих транспортних вузлах, а i врахування причин, що визначають вибір пасажиром способу переміщення і виду транспортних засобів.

Основна частина дослідження. При формуванні комплексної транспортної системи великих міст слід враховувати причини, що визначають вибір пасажиром спосіб переміщення i вид транспортних засобів: соціальні, психологічні і демографічні. У першу чергу пасажир великого міста при виборі маршруту пересування прораховує, скільки витрачається на поїздку часу. Тому фактор часу є одним з основних параметрів, що впливають на вибір виду транспорту, за умови, що пасажира задовольняє вартість проїздки цим видом транспорту і якість обслуговування в ньому.

Скорочення часу поїздки в межах міста можливо за рахунок збільшення швидкостей руху транспортних засобів при організації швидкісних внутрішньоміських і приміських перевезень залізничним або іншим видом транспорту 3 мінімальною кількістю зупинок [5]. Для організації швидкісних міських i приміських перевезень, як правило, необхідним $\epsilon$ спорудження додаткових головних колій на головних ділянках і розв'язок.

Істотне скорочення часу поїздки пасажира $з$ початкового пункту до кінцевого за рахунок збільшення швидкості руху транспортних засобів на окремих ділянках спільного шляху може не відбутися через тривалий час перебування пасажирав ТПВ при пересадці між взаємодіючими видами транспорту. У більшості випадків цей час безпосередньо визначається нераціональною планувальною організацією ТПВ i недостатньою координацією в роботі взаємодіючих у ТПВ видів транспорту. Тому одним 3 головних завдань, вирішення якого дозволить скоротити загальний час поїздки пасажира, $є$ вибір раціональних параметрів ТПВ як центрів взаємодії швидкісного залізничного та інших видів пасажирського транспорту.

Вирішення завдання вибору параметрів ТПВ, що формуються за участю швидкісного залізничного транспорту, $\epsilon$ складовою частиною наукового завдання раціоналізації структури ТПВ на основі закономірностей формування пасажиропотоків, спрямованого на підвищення ефективності управління пасажирськими перевезеннями та поліпшення рівня сервісу на високошвидкісних залізничних магістралях.

Сьогодні ТПВ - багатовимірний за параметрами i багатофункціональний за функціями і структурою транспортний об'єкт. Таким чином, проблеми формування, функціонування і розвитку ТПВ великих міст перебувають у сфері функціонування окремих їх груп подаються як:

- пункти взаємодії різних видів пасажирського транспорту як зовнішніх, так i внутрішніх;

- елементи швидкісного пасажирського комплексу залізничноготранспорту.

Структура, характер i напрям транспортних потоків являють собою головні фактори, що визначають транспортнопланувальну структуру ТПВ. В даний час пасажирів, які користуються транспортом, можна поділити на три групи залежно від їхніх пріоритетів, що визначають привабливість того чи іншого виду транспорту:

- вартість поїздки від пункту відправлення до пункту призначення; 


\section{Експлуатація залізниць}

- час, що витрачається на поїздку від пункту відправлення до пункту призначення пасажира (з урахуванням часу на пересадку між видами транспорту та очікування транспорту);

- рівень сервісу.

У сучасних умовах до основних напрямів розвитку сервісу пасажирських перевезень у великих транспортних вузлах відносять:

- розширення транспортної мережі внутрішньоміських перевезень;

- розширення мережі метрополітену;

- створення системи «перехоплюючих» парковок;

- розвиток таксомоторних послуг;

- розвиток інтелектуальних транспортних систем (встановлення детекторів руху, адаптивних інформаційних табло, засобів дистанційної діагностики);

- інтеграція рішень у сфері проїзних документів i тарифної політики (створення єдиного інтермодального квитка та автоматизація системи продажів);

- збільшення провізної і пропускної спроможності магістралей;

- спорудження ТПВ 3 метою стимулювання використання громадського транспорту в межах міста;

- розвиток нових швидкісних магістральних видів транспорту;

- впровадження сучасних методів, техніки i технологій для аналізу i прогнозування транспортних ситуацій;
- прискорена доставка дрібних вантажів і багажу швидкісним залізничним транспортом.

Всі рішення повинні бути спрямовані на загальне завдання підвищення популярності швидкісного залізничного транспорту. У зарубіжній практиці проектування планувальної структури багатофункціональних ТПВ швидкісного залізничного транспорту накопичено багатий досвід. Наприклад, комплексна модернізація транспортної інфраструктури, що проводиться в Японії в останні роки, дозволила досягти глибокої інтеграції систем міжрегіонального, регіонального залізничного, автомобільного i міських видів пасажирського транспорту. ТПВ на базі вокзального комплексу «Токійський вокзал», де взаємодіють різні види міського (позавуличного швидкісного i наземного пасажирського транспорту), регіонального (приміські електропоїзди) і зовнішнього (поїзди швидкісні системи «Синкансен») транспорту, що забезпечують транспортну доступність об'єктів практично 3 усієї території Японії. Планувальне рішення вузла пересадки пасажирів 3 одного виду транспорту на інший у вигляді ТПК 3 розподільним рівнем, розташованим у надземному або підземному просторі, - основне планувальне рішення, характерне для великих ТПВ в Японії. Компактність планувальної організації, що досягається за рахунок багаторівневого рішення, використано, наприклад, у ТПВ «Одайбо» (рис. 1).

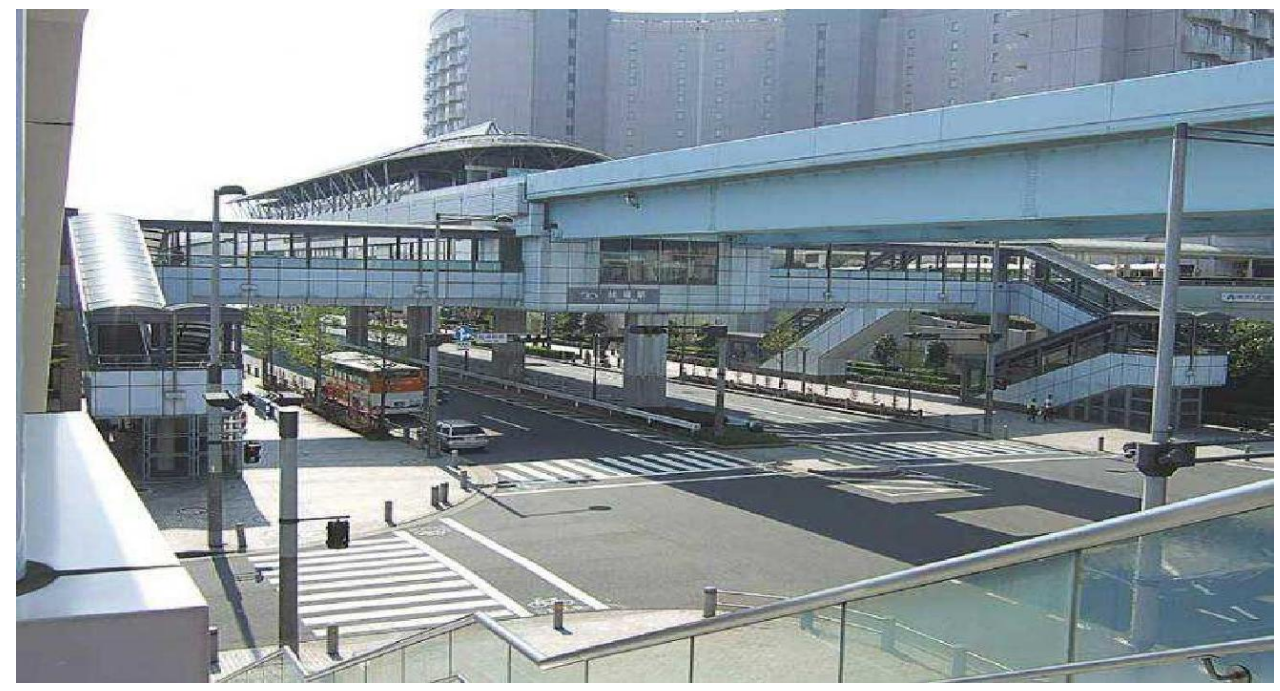

Рис. 1. Загальний вигляд ТПВ «Одайбо» 
Аналіз співвідношення часток площ ТПВ подано на рис. 2. Досвід експлуатації ТПВ показує необхідність зниження частки комерційних площ, віддавши перевагу пішохідним i транспортним зонам, сервісцентрам, що забезпечує виконання основної функції - швидка, зручна, безпечна пересадка пасажирів з одного виду транспорту на інший.
Отже, ТПВ можна визначити як складний інфраструктурний комплекс, що включає в себе земельні ділянки з розташованими на них, над ними чи під ними об'єктами транспортного та іншого призначення i призначений для забезпечення безпечного й комфортного обслуговування пасажирів у місцях пересадок 3 одного виду транспорту на інший [9].

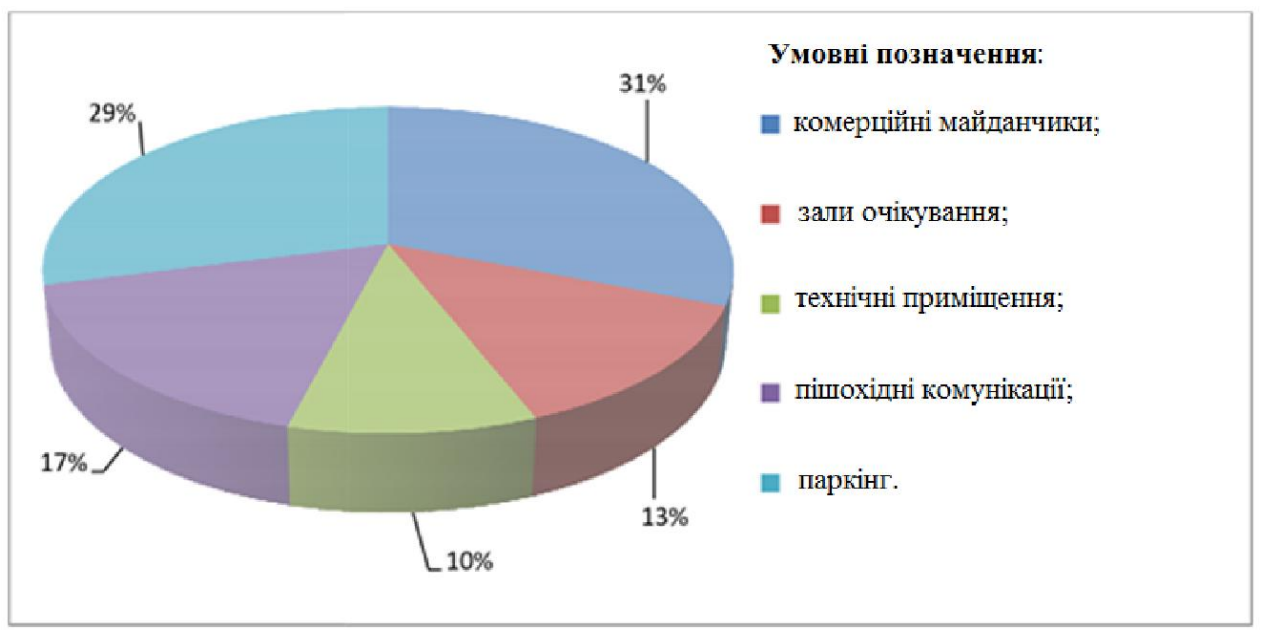

Рис. 2. Співвідношення основних часток площ ТПВ

Вдосконалена порівняно 3 роботою [5] класифікація ТПВ у вигляді структурної схеми включає транспортну та містобудівну складову (рис. 3). Крім згаданих характеристик для ТПВ за участю швидкісного залізничного транспорту, запропоновано використовувати додаткові критерії - планувальне рішення ТПВ, наявність і розміщення сервіс-центру, наявність перехоплювального паркування. $\begin{array}{ccr}\quad \text { Підвищення } & \text { рівня } & \text { сервісного } \\ \text { обслуговування } & \text { передбачає } & \text { надання }\end{array}$ додаткових послуг пасажирам і відвідувачам ТПВ. У зоні додаткового обслуговування пасажирів і відвідувачів організуються супутні об'єкти сервісного обслуговування, що надають послуги, які, 3 одного боку, доповнюють основну транспортну послугу, а 3 іншого підвищують комерційну та інвестиційну привабливість всього ТПВ. Головний напрям розвитку супутніх бізнесів у ТПВ - здача в оренду площ громадських зон, що забезпечує збалансовану структуру портфеля супутніх продуктів і послуг. Аналіз ТПВ, наведений у роботах $[5,9]$, дозволив сформувати перелік можливих додаткових послуг, що надаються пасажирам і відвідувачам ТПВ (рис. 4).

Важливим моментом у формуванні раціональної планувальної структури ТПВ $\epsilon$ вирішення питання зонування площ ТПВ за видами послуг, що надаються пасажирам i відвідувачам. Аналіз показав, що 3 усього різноманіття критеріїв можна виділити три основні критерії ефективності зонування площ ТПВ:

1. Задоволеність користувачів дозволяє оцінити ефективність використання приміщень ТПВ $з$ точки зору його користувачів. При цьому ступінь насичення товарами і послугами повинна відповідати обсягам потреб користувачів ТПВ.

2. Рентабельність додаткових видів послуг, що надаються в ТПВ, дозволяє зробити висновок про необхідність і доцільність надання окремих видів додаткових послуг.

3. Дохід на $1 \mathrm{~m}^{2}$ дозволяє оцінити ефективність використання приміщень, зробити висновки про найбільш прибуткові види послуг i ефективність зонування приміщень ТПВ згідно з переліком наданих послуг. 


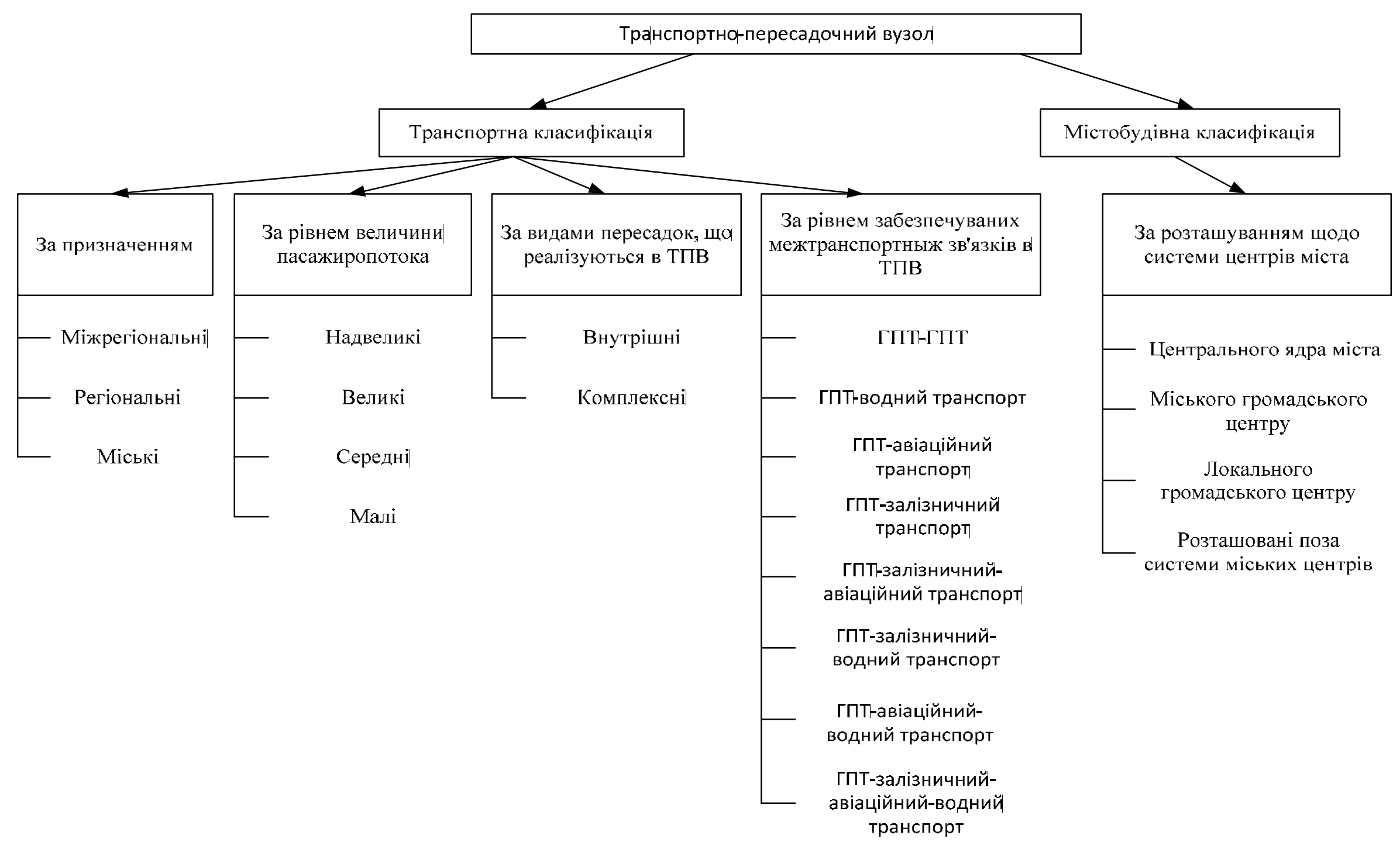

Рис. 3. Класифікація транспортно-пересадочних вузлів 

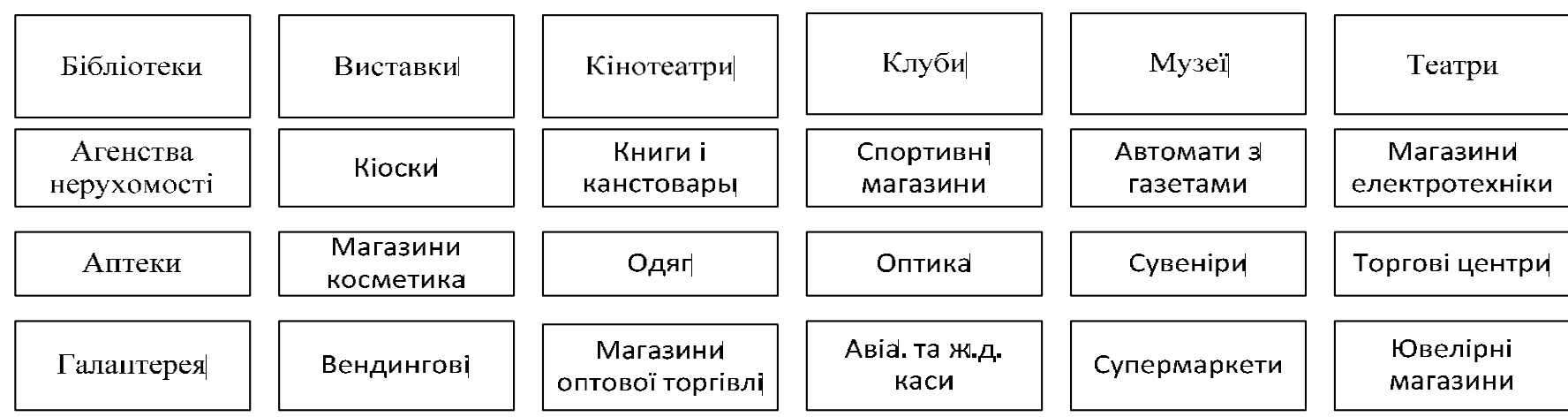

Магазини
косметика
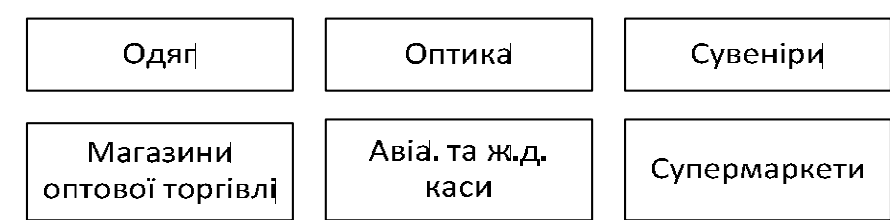

Торгові центри

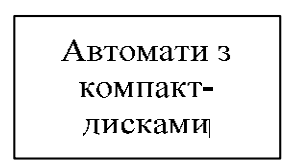

Вендингові

\begin{tabular}{c} 
Магазини \\
оптової торгівлі \\
\hline
\end{tabular}

\begin{tabular}{|c|}
\hline Автомати з \\
предметами \\
особистої \\
гігієни \\
\hline Автомати 3 \\
гарячими \\
обідами \\
\hline
\end{tabular}

\begin{tabular}{|c|}
\hline $\begin{array}{c}\text { Магазини } \\
\text { побутової хімії }\end{array}$ \\
\hline $\begin{array}{c}\text { Магазини } \\
\text { швидкого } \\
\text { харчування }\end{array}$ \\
\hline
\end{tabular}

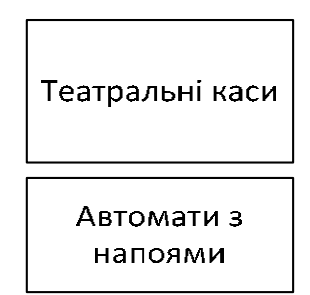

Супермаркети

Ювелірні

магазини

\begin{tabular}{l} 
Автомати з \\
чаєм, кавою, \\
бульйонами \\
\hline
\end{tabular}

\begin{tabular}{|c|}
\hline обідами \\
\hline Кафе \\
\hline Автомати для \\
копіювання \\
\hline
\end{tabular}
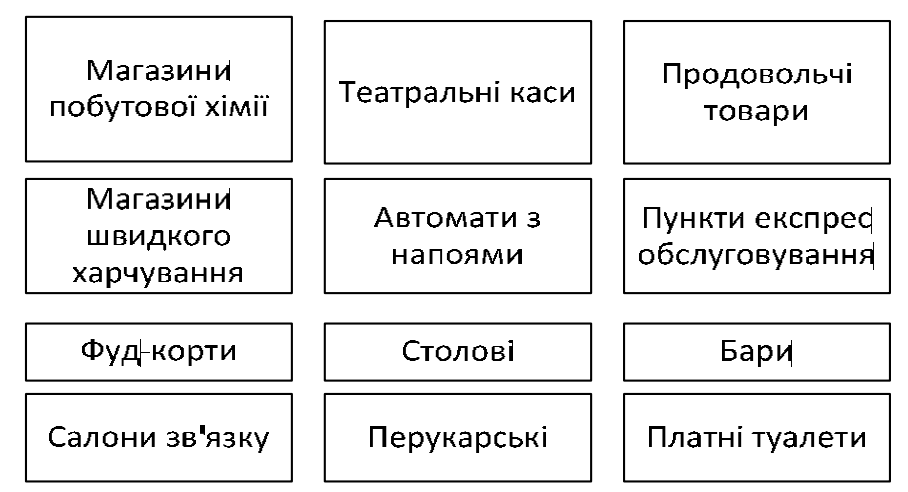

\begin{tabular}{|c|}
\hline $\begin{array}{c}\text { Філії великих } \\
\text { фірмових } \\
\text { магазинів }\end{array}$ \\
\hline $\begin{array}{c}\text { Автоматами з } \\
\text { морозивом }\end{array}$ \\
\hline
\end{tabular}

\begin{tabular}{|c|}
\hline Ресторани \\
\hline $\begin{array}{l}\text { Платіжні } \\
\text { системи }\end{array}$ \\
\hline
\end{tabular}
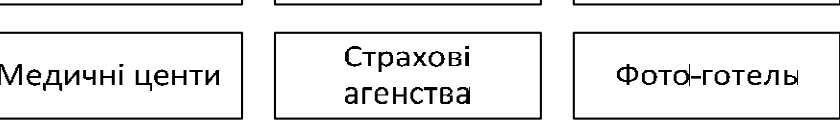

Пункти експрес обслуговування

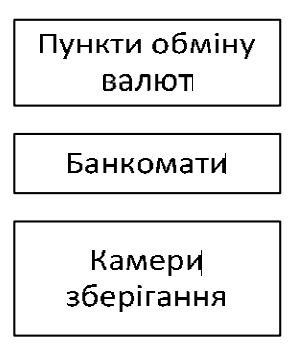

Медичні центи

агенства

\begin{tabular}{|c|}
\hline Бари \\
\hline Платні туалети \\
\hline
\end{tabular}

Піцерії

Інтернет-кафе

\begin{tabular}{|c|}
\hline Ломбард \\
\hline Пункти \\
юредических \\
послуг \\
\hline
\end{tabular}

\begin{tabular}{|c|}
\hline Пошта \\
\hline Пункти ремонту \\
(взуття, \\
годинники) \\
\hline
\end{tabular}

\begin{tabular}{|l|}
\hline Тур-агенства \\
\hline $\begin{array}{c}\text { Флористичні } \\
\text { магазини }\end{array}$ \\
\hline
\end{tabular}

\begin{tabular}{l}
$\begin{array}{c}\text { Тренажерні } \\
\text { зали }\end{array}$ \\
\hline Хімчистки \\
\hline Спортивні зали \\
\hline
\end{tabular}

Пральня

Готелі

Рис. 4. Додаткові сервісні послуги, що надаються пасажирам і відвідувачам ТПВ 


\section{Експлуатація залізниць}

Одним 3 основних якісних параметрів функціонування ТПВ за участю швидкісного залізничного транспорту $\epsilon$ відстань, яку необхідно подолати пасажиру, щоб здійснити пересадку з одного виду транспорту на інший. При цьому досвід показує, що максимальна дальність пішого проходу при пересадці не повинна перевищувати 100-150 м, а час на пересадку 3-5 хвилин. Отже, при розрахунку параметрів ТПВ, що формуються за участю швидкісного залізничного транспорту, може бути також використаний особливий показник - площа, яка припадає на одного пасажира $\mathrm{p}$ $\left(\mathrm{M}^{2} /\right.$ пас) у процесі руху. Графік залежності щільності пасажиропотоку D $\left(\right.$ пас/ $\left.\mathrm{M}^{2}\right)$ i пропускної спроможності одного метра ширини комунікаційних шляхів Q залежно від значень р наведено на рис. 5.

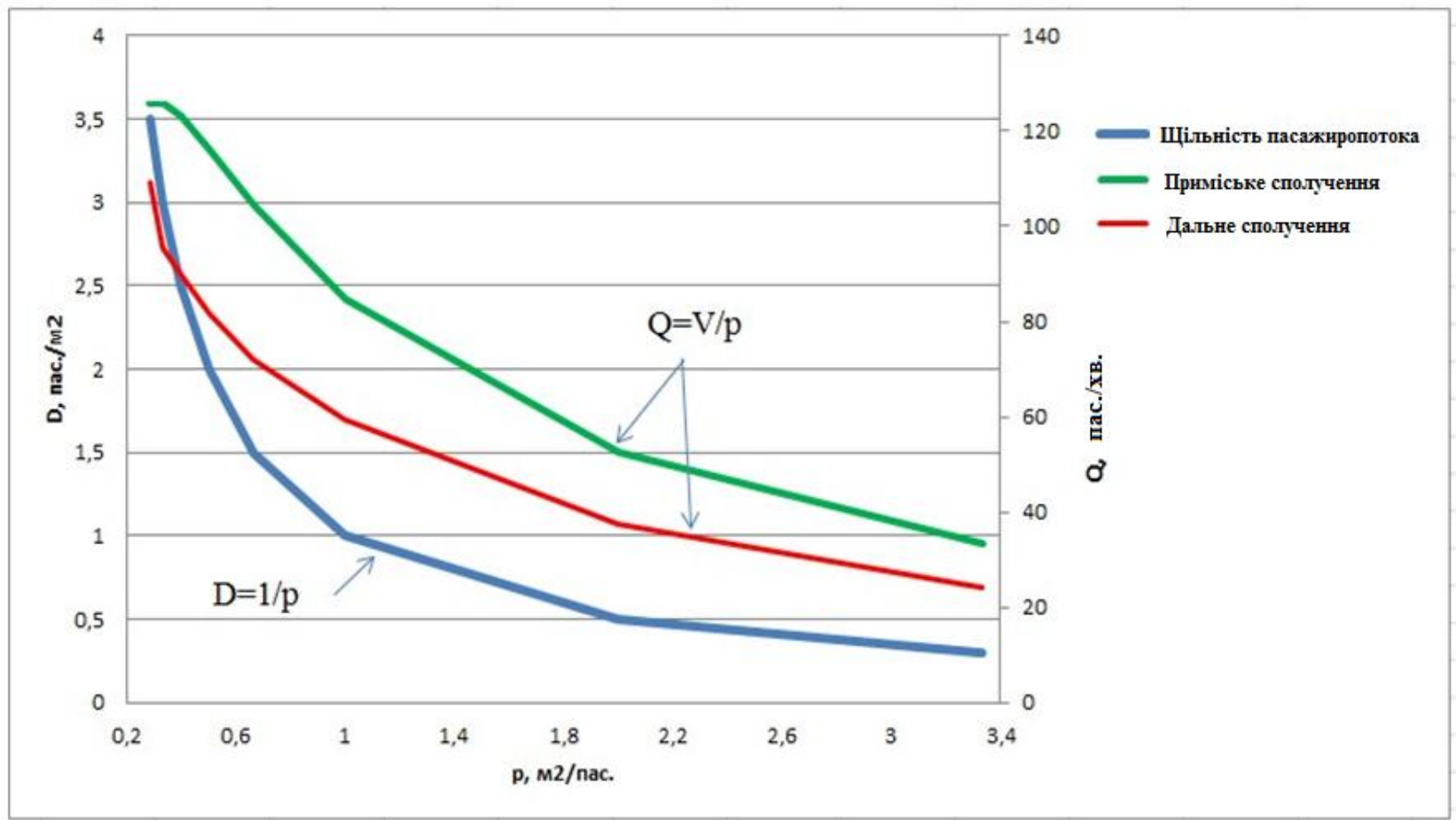

Рис. 5. Залежність щільності пасажиропотоку пропускної спроможності одного метра ширини комунікаційних шляхів від значень $\mathrm{p}$

Висновок. Великі ТПВ характеризуються значною нерівномірністю пасажиропотоків за періодами доби. Найбільший потік спостерігається в ранкові та вечірні години пік. Пояснюється це тим, що обсяги максимальних добових пасажиропотоків утворюються саме в цей період і зазвичай їх частка складає до 50 \% добового потоку пасажирів ТПВ.

Таким чином, аналіз зарубіжного досвіду формування та розвитку ТПВ виділив основні тенденції, пов'язані 3 формуванням комплексних ТПВ, у яких взаємодіють швидкісний залізничний, автомобільний i внутрішні види транспорту. Крім того, встановлено необхідність концентрації та оптимізації кількості ТПВ в містах 3 метою раціоналізації використовуваних міських територій i зменшення кількості пересадок пасажирів.

\section{Список використаних джерел}

1. Артынов, А.П. Управление взаимодействием транспортных систем [Текст] / А.П. Артынов, Г.А. Кондратьев. - М.: Наука, 1986. - 198 с. 


\section{Експлуатація залізниць}

2. Каретников, А.Д. Координация работы различных видов транспорта [Текст] / А.Д. Каретников, А.В. Комаров. - М.: Транспорт, 1964. - 200 с. 1995.

3. Helbing, D. Socialforcemodelforpedestriandynamics [Text] / D. Helbing // Physicalreview E, May

4. Alonso, W. LocationandLandUse [Text] / W. Alonso // Cambridge (Mass), Harvard University Press, 1964.

5. Вакуленко, С.П. Формирование транспортно-пересадочных узлов в зонах тяготения пассажиропотоков пригородных зон [Текст] / С.П. Вакуленко, Н.Ю. Евреенова // Труды Междунар. научно-практической конференции «Проблемы и перспективы развития транспорта». - М.: МИИТ, 2012. - С. 90-92.

6. Скалов, К.Ю. Методика технико-экономическихрасчетов при развитии транспортных узлов [Текст] / К.Ю. Скалов, Э.Е. Островский, Г.С. Молярчук. - М.: Транспорт, 1972. - 567 с.

7. Сорокин, А.А. Моделирование городских пассажирских перевозок [Текст]: дисс... канд. экон. наук: 08.00.13 / А.А. Сорокин. - Ставрополь: Ставропольский государственный университет, 2005. $-198 \mathrm{c}$.

8. Торопов, Б.И. Развитие пассажирских комплексов на основе закономерностей формирования пассажиропотоков [Текст]: дисс... канд. техн. наук: 05.22 .00 / Б.И. Торопов. - К., Киевский институт железнодорожного транспорта, 2000. - 154 с.

9. Евреенова, Н.Ю. Выбор параметров транспортно-пересадочных узлов, формируемых с участием железнодорожного транспорта [Текст]: дисс... канд. техн. наук: 05.22 .08 / Н.Ю. Евреенова. - М.: Московский государственный университет путей сообщения, 2014. -255 с.

10. Резер, С.М. Логистика пассажирских перевозок на железнодорожном транспорте [Текст] / С.М. Резер. - М.: ВИНИТИ РАН, 2007. - 516 c.

11. Угрюмов, А.К. Оперативное управление движением на железнодорожном транспорте [Текст] / А.К. Угрюмов. - М.: Транспорт, 1983. - 239 с.

Ломотько Денис Вікторович, д-р техн. наук, професор кафедри управління вантажною та комерційною роботою, Український державний університет залізничного транспорту. Тел.: (057) 730-10-05.

Марасіна Ірина Євгенівна, магістрант кафедри управління вантажною та комерційною роботою, Український державний університет залізничного транспорту. Тел.: (057) 730-10-05.

Lomotko Denis Viktorovich, doctor of technical Sciences, Professor of Department of management of freight and commercial work, Ukrainian state University of railway transport. Tel.: (057) 730-10-05.

Marasina Irina Yevhenivna, magistrand of Department of management of freight and commercial work, Ukrainian state University of railway transport. Tel.: (057) 730-10-05.

Наукова праця здана до друку 22.06.2015 року 